\title{
Measurement of prostaglandin E2 in cerebrospinal fluid in patients suffering from stroke
}

R. L. C A R A S S O, J . V A R D I, J . M . R A B A Y, U . Z O R, A N D M . S T R E I F L E R

From the Department of Neurology, Municipal Governmental Medical Center, Ichilov Hospital, Tel-Aviv University Medical School, and the Department of Hormone Research, The Weizman Institute of Science, Rechovoth, Israel

SUMMARY In 16 patients suffering from cerebrovascular events, prostaglandin (PG) E2 was measured in their cerebrospinal fluid and correlated with their clinical status and evolution. Prostaglandin E2 ranged from $200-3000 \mathrm{pg}$ (picogram)/ml of cerebrospinal fluid. A positive correlation was found between PG E2 levels and the severity and clinical outcome of the stroke.

Prostaglandins (PG) which have different biological activities have been identified in human brain (Holmes and Horton, 1968; Pennink et al., 1972). Data available at present indicate that PG synthesised in brain in vivo appear in the cerebrospinal fluid, are activately taken up by the choroid plexus and transported into the venous circulation and removed by extra-neuronal tissues (Bito, 1972a,b). Thus CSF, in contrast to plasma (Samuelsson, 1972), might be expected to contain measurable levels of PG. Several studies (White et al., 1971; Denton et al., 1972; Pelofsky et al., 1972; Yamamoto et al., 1972; Nakano et al., 1973; Greenberg et al., 1974; La Torre et al., 1974) have shown that some of them such as PG F2 alpha are potent vasoconstrictor agents on cerebral arteries, while PG of the E type are vasodilators.

Cerebrovascular events are followed by the liberation of different vasoactive agents (Wurtman and Zervas, 1974; Lavyne et al., 1975). In our study we found a positive correlation between PG E2 levels in CSF and the severity of a stroke.

\section{Patients and methods}

Sixteen patients suffering from suspected cerebral vascular events were admitted to Ichilov Hospital at random for clinical investigation. The clinical characteristics of the patients and findings of the investigations are summarised in Table 1 . The mean age was 62.2 years (range 38 to 82 years).

Address for correspondence and reprint requests: Dr R. L. Carasso, Department of Neurology, Municipal Governmental Medical Center, Ichilov Hospital, Tel-Aviv, Israel.

Accepted 9 May 1977
There were seven men and nine women. Eight patients suffered from hypertension, five from diabetes mellitus, three of these had both hypertension and diabetes. Two patients had a history of myocardial infarction.

The investigations included clinical examination, laboratory examination with measurement of coagulation factors, ECG, chest and skull radiographs, EEG, and isotopic brain scan in the first week and one month from the event. Four vessels angiography was done in 13 patients. Lumbar puncture was performed during the first 72 hours after admission for routine studies and PG E2 determination. Cerebrospinal fluid without any extraction was used for determination of PGE concentration by radioimmunoassay (Bauminger et al., 1973). No drugs with known anti-PG activities were added to the treatment. The patients were treated only with Hartmann (Ringer lactate) solution and glucose 5\%. Manitol and diuretics were used when necessary.

The patients were classified into two groups: (a) mild to moderate cerebrovascular accidentpatients who suffered from paresis which improved during one month (five patients), and (b) moderate to severe cerebrovascular accident-patients who developed changes of consciousness and paralysis that did not improve enough during the first month (11 patients of whom five died).

The patients were followed up after the cerebrovascular event for nine to 12 months.

\section{Results}

The PG E2 levels in CSF, summarised in Table 2, 
Table 1 Clinical and laboratory characteristics of 16 patients suffering from stroke

\begin{tabular}{|c|c|c|c|c|c|c|c|c|}
\hline $\begin{array}{l}\text { Patient } \\
\text { number }\end{array}$ & $\begin{array}{l}\text { Age } \\
(y r)\end{array}$ & $\operatorname{Sex}$ & Medical history & Main clinical feature & Angiography & $E E G$ & First brain scan & Second brain scan \\
\hline 1 & 69 & $\mathbf{F}$ & $\begin{array}{l}\text { Hypertension, } \\
\text { diabetes mellitus }\end{array}$ & $\begin{array}{l}\text { Left hemiplegia, } \\
\text { stupor, death }\end{array}$ & $\begin{array}{l}\text { Right carotid } \\
\text { occlusion }\end{array}$ & $* *$ & Mild positive & $* *$ \\
\hline 2 & 58 & $\mathbf{M}$ & $\begin{array}{l}\text { Hypertension, } \\
\text { diabetes mellitus } \\
\text { myocardial infarction }\end{array}$ & $\begin{array}{l}\text { Left hemiplegia, } \\
\text { coma, death }\end{array}$ & $\begin{array}{l}\text { Right carotid } \\
\text { occlusion }\end{array}$ & $* *$ & Mild positive & $* *$ \\
\hline 3 & 82 & $\mathbf{F}$ & & $\begin{array}{l}\text { Right hemiplegia, } \\
\text { aphasia, confusion, } \\
\text { death }\end{array}$ & Normal & $* *$ & Mild positive & $* *$ \\
\hline 4 & 70 & $\mathbf{M}$ & Hypertension & $\begin{array}{l}\text { Coma, bilateral } \\
\text { Babinski signs }\end{array}$ & $\begin{array}{l}\text { Basilar artery } \\
\text { occlusion }\end{array}$ & $* *$ & Normal & $* *$ \\
\hline 5 & 38 & $\mathbf{F}$ & & $\begin{array}{l}\text { Left hemiparesis, } \\
\text { coma, death }\end{array}$ & Normal & $* *$ & Mild positive & ** \\
\hline 6 & 60 & $\mathbf{M}$ & $\begin{array}{l}\text { Hypertension, } \\
\text { myocardial infarction }\end{array}$ & $\begin{array}{l}\text { Neck rigidity, } \\
\text { right paresis, } \\
\text { dysphasia, confusion }\end{array}$ & Normal & $* *$ & Normal & Normal \\
\hline 7 & 72 & $\mathbf{M}$ & Diabetes mellitus & $\begin{array}{l}\text { Right hemiplegia, } \\
\text { stupor }\end{array}$ & Normal & $* *$ & Normal & Normal \\
\hline 8 & 65 & $\mathbf{F}$ & & $\begin{array}{l}\text { Meningism, } \\
\text { Left paresis }\end{array}$ & $* *$ & $* *$ & Mild positive & Normal \\
\hline 9 & 60 & $\mathbf{F}$ & Hypertension & $\begin{array}{l}\text { Vertigo, vomiting, } \\
\text { cortical blindness }\end{array}$ & $\begin{array}{l}\text { Basilar artery } \\
\text { occlusion }\end{array}$ & Normal & Mild positive & Normal \\
\hline 10 & 55 & $\mathbf{M}$ & $\begin{array}{l}\text { Hypertension, } \\
\text { diatetes mellitus }\end{array}$ & $\begin{array}{l}\text { Right hemiplegia, } \\
\text { vertigo, confusion }\end{array}$ & $\begin{array}{l}\text { Left internal } \\
\text { carotid artery } \\
\text { occlusion }\end{array}$ & $* *$ & Normal & Normal \\
\hline 11 & 36 & $\mathbf{F}$ & & $\begin{array}{l}\text { Right hemiparesis, } \\
\text { old epilepsy }\end{array}$ & $\begin{array}{l}\text { Left middle } \\
\text { cerebral artery } \\
\text { occlusion }\end{array}$ & $* *$ & Normal & Normal \\
\hline $\begin{array}{l}12 \\
13\end{array}$ & $\begin{array}{l}67 \\
81\end{array}$ & $\begin{array}{l}\mathbf{M} \\
\mathbf{M}\end{array}$ & $\begin{array}{l}\text { Myocardial infarction } \\
\text { Hypertension }\end{array}$ & $\begin{array}{l}\text { Hemiparesis } \\
\text { Mild left } \\
\text { hemiparesis }\end{array}$ & $\begin{array}{l}\text { Normal } \\
* *\end{array}$ & $\begin{array}{l}\text { Normal } \\
\text { Normal }\end{array}$ & $\begin{array}{l}\text { Normal } \\
\text { Normal }\end{array}$ & $\begin{array}{l}\text { Normal } \\
\text { Normal }\end{array}$ \\
\hline 14 & 64 & $\mathbf{M}$ & Diabetes mellitus & $\begin{array}{l}\text { Mixed aphasia, } \\
\text { right paresis }\end{array}$ & $* *$ & Normal & Normal & Normal \\
\hline 15 & 53 & $\mathbf{F}$ & Hypertension & Right hemiparesis & $\begin{array}{l}\text { Left middle } \\
\text { cerebral artery } \\
\text { occlusion }\end{array}$ & $* *$ & Normal & Normal \\
\hline 16 & 70 & $\mathbf{M}$ & & Left paresis & Normal & Normal & Normal & Normal \\
\hline
\end{tabular}

** = Examination not performed.

Table 2 CSF prostaglandin E2 level and severity of stroke

\begin{tabular}{llll}
\hline & & \multicolumn{2}{l}{$C S F$} \\
\cline { 3 - 4 } $\begin{array}{lll}\text { Patient } \\
\text { number }\end{array}$ & Severity of stroke & $\begin{array}{l}\text { Levels of } \\
\text { PG E2 }(\mathrm{pg} / \mathrm{ml})\end{array}$ & Protein $(\mathrm{g} / \mathrm{l})$ \\
\hline 1 & Died & 1000 & 8.0 \\
2 & Died & 1300 & 6.0 \\
3 & Died & 500 & 4.5 \\
4 & Died & 200 & 3.2 \\
5 & Died & 1500 & 8.8 \\
6 & Severe stroke & 3000 & 10.4 \\
7 & Moderate to severe & 500 & 4.0 \\
8 & Moderate to severe & 350 & 3.4 \\
9 & Moderate to severe & 720 & 4.2 \\
10 & Moderate to severe & 215 & 3.8 \\
11 & Moderate to severe & 200 & 3.7 \\
12 & Mild to moderate & 200 & 8.5 \\
13 & Mild to moderate & 100 & 2.2 \\
14 & Mild to moderate & 150 & 7.0 \\
15 & Mild to moderate & 150 & 3.0 \\
16 & Mild to moderate & 150 & 3.6 \\
\hline
\end{tabular}

Normal values of CSF prostaglandin E2 levels are $<70 \mathrm{pg} / \mathrm{ml}$. Normal values of CSF protein levels are $<4.5 \mathrm{~g} / \mathrm{l}$.

ranged from 100 to $3000 \mathrm{pg} / \mathrm{ml}$ and showed a positive correlation with the clinical outcome. The patients who suffered from mild to moderate strokes as defined above had CSF prostaglandin E2 levels which ranged from 100 to $200 \mathrm{pg} / \mathrm{ml}$. Patients who suffered from moderate to severe cerebrovascular attacks had levels which ranged from 200 to $3000 \mathrm{pg} / \mathrm{ml}$. Five patients died during the first month; the brain scan was moderately positive in four cases and negative in one; two showed internal carotid artery occlusion and one basilar artery occlusion on angiography, and another two patients had normal angiograms. Postmortem examination could not be done because of family resistance. Their PG E2 levels in CSF ranged from 800 to $3000 \mathrm{pg} / \mathrm{ml}$.

\section{Diszussion}

Different vasoactive agents are liberated after a cerebrovascular accident. Their exact role in the evolution of the disease has not yet been determined. These agents may be involved in the loss of autoregulation and the development of vasoparalysis. Prostaglandin E2, one of those vasoactivated agents which is present at high levels in CSF, may affect the evolution of vascular events 
by inhibition of platelet aggregation and by a local vasodilator effect (Nakano et al., 1972). These two biological actions may contribute to the increased hyperaemia described as the 'luxury perfusion syndrome' (Høedt-Rasmussen et al., 1967; Paulson et al., 1970). The inhibition of platelet aggregation and vasodilator effect of PG E2 released locally in the affected area, may cause a 'haemorrhagic infarct' and aggravate the clinical condition of the patient.

Prostaglandin E2 is synthesised from phospholipids via arachidonic acid of the cell membrane as illustrated in the Figure. It may be postulated that there is a positive correlation between the magnitude of neural tissue necrosis and the levels of PG E2, a possibility supported by the present study. From a therapeutic point of view it will be of interest to treat strokes with anti-prostaglandin drugs.

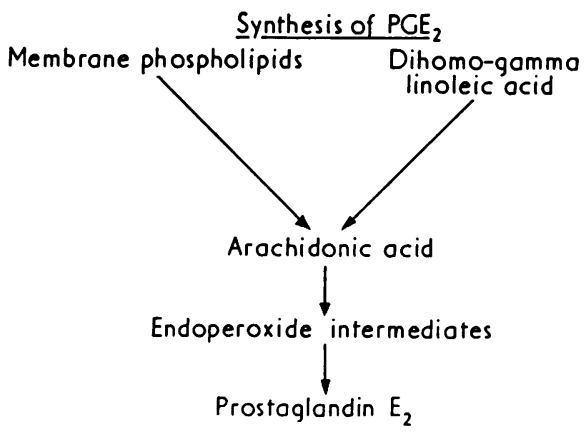

Figure Diagram of the synthesis of prostaglandin E2.

\section{References}

Bauminger, S., Zor, U., and Lindner, H. R. (1973). Radioimmunoassay of prostaglandin synthetase activity. Prostaglandins, 4, 313.

Bito, L. Z. (1972a). Accumulation and apparent active transport of prostaglandins by some rabbit tissue in vitro. Journal of Physiology (London), 221, 371-387.

Bito, L. Z. (1972b). Comparative study of concentrative prostaglandin accumulation by various tissues of mammals and marine vertebrates and invertebrates. Comparative Biochemistry and Physiology (England), 43, 65-82.

Denton, I. C., Jr., White, K. P.. and Robertson, J. T. (1972). The effects of prostaglandins E1, A1, and F2 alpha on the cerebral circulation of dogs and monkeys. Journal of Neurosurgery, 36, 34-43.

Greenberg, S., Wilson, W. R., and Howard, L. (1974). Mechanism of the vasoconstriction of prostaglandin.
British Journal of Pharmacology and Experimental Therapy, 190, 59-69.

Høedt-Rasmussen, K., Skinhøj, E., Paulson, O., Ewald, J., Bjerrum, J. K., Fahrenkrug, A., and Lassen, N. A. (1967). Regional cerebral blood flow in acute apoplexy: The 'luxury perfusion syndrome' of brain tissue. Archives of Neurology (Chicago), 17, 271281.

Holmes, S. W., and Horton, E. W. (1968). The identification of four prostaglandins in the dog brain and their regional distribution in the central nervous system. Journal of Physiology (London), 195, 731741.

La Torre, E., Patrono, C., and Fortuna, A. (1974). Role of prostaglandin $F 2$ alpha in human cerebral vasospasm. Journal of Neurosurgery, 41, 293-299.

Lavyne, M. H., Moskowitz, M. A., Larin, F., Zervas, N., and Wurtman, R. J. (1975). Brain H3 catecholamine metabolism in experimental cerebral ischemia. Neurology (Minneapolis), 25, 483-485.

Nakano, J., Chang, A. C. K., and Fisher, R. G. (1973). Effects of prostaglandins E1, E2, A1, A2, and F2 alpha on canine carotid arterial blood flow, cerebrospinal fluid pressure and intraocular pressure. Journal of Neurosurgery, 38, 32-39.

Nakano, J., Pracan, A. V., and Moose, S. E. (1972). Metabolism of prostaglandin E1 in cerebral cortex and cerebellum of the dog and rat. Brain Research, 39, 545-548.

Paulson, O. B., Lassal, N. A., and Skinhøj, E. (1970). Regional cerebral blood flow in apoplexy without arterial occlusion. Neurology (Minneapolis), 20, 125-138.

Pelofsky, S., Jacobson. E. D., and Fisher, R. G. (1972). Effects of prostaglandin E1 on experimental cerebral vasospasm. Journal of Neurosurgery, 36, 634639.

Pennink, M., White, R. O., Crockarell, J. T., and Robertson, J. T. (1972). Role of prostaglandin F2 alpha in the genesis of experimental vasospasm. Journal of Neurosurgery, 37, 398-406.

Samuelsson, B. (1972). Quantitative aspects of prostaglandin synthesis in man. Advances in the Biosciences, 9, 7-14.

White, R. P., Heston, J. A., and Denton, I. C. (1971). Pharmacologic comparison of prostaglandin F2 alpha, serotonin and norepinephrine on cerebrovascular tone of monkey. European Journal of Pharmacology, 15, 300-309.

Wurtman. R. J., and Zervas, N. T. (1974). Monoamine neurotransmitters and the pathophysiology of stroke and central nervous system trauma. Journal of Neurosurgery, 40, 34-36.

Yamamoto, Y. L., Feindel, W., Wolfe, L. S., Katoh, H., and Hodee. Ch. P. (1972). Experimental vasoconstriction of cerebral arteries by prostaglandins. Journal of Neurosurgery, 37, 385-397. 